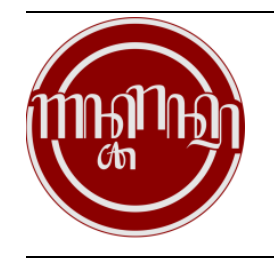

GHÂNCARAN: JURNAL PENDIDIKAN BAHASA DAN SASTRA INDONESIA

http://ejournal.iainmadura.ac.id/index.php/ghancaran E-ISSN : 2715-9132; P-ISSN: 2714-8955 DOI 10.19105/ghancaran.vi.5397

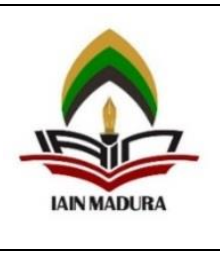

\title{
Unsur Keteladanan Tokoh dalam Buku Digital H.B. Jassin: Perawat Sastra Indonesia sebagai Bahan Ajar Bahasa Indonesia
}

\author{
Dian Etikasari*, Rahmawati Mulyaningtyas** \\ * Tadris Bahasa Indonesia, UIN Sayyid Ali Rahmatullah Tulungagung \\ ** Tadris Bahasa Indonesia, UIN Sayyid Ali Rahmatullah Tulungagung \\ Alamat surel: etikadian@gmail.com
}

\begin{abstract}
\begin{tabular}{ll}
\hline \hline & Abstract: \\
\hline Keywords: & The younger generation possess problems in recognizing the
\end{tabular}
great role model; national figures who have contributed greatly to the
Indonesian

lndonesian

language

teaching

material. Indonesian nation. The Ministry of Education and Culture by its digital library releases the site budi.kemdikbud.go.id which provides the books that are very useful for children in recognizing Indonesian national figures. One of the books is entitled H.B Jassin: Perawat Sastra Indonesia which contains about the ins and outs of H.B Jassin that gives a great role model. This can be used as a role model for children in building their character development. In addition, the digital book H.B Jassin: Perawat Sastra Indonesia can be used as a teaching material for Indonesian language learning. The purpose of this research is to describe the noble attitude of H.B Jassin and the use of the digital book H.B Jassin: Perawat Sastra Indonesia as Indonesian language teaching material. Descriptive qualitative was chosen as the research method an digital book H.B Jassin: Perawat Sastra Indonesia as the source data. From the results of the analysis, it was found that the noble character elements of H.B. Jassin, they are fond of reading, passionate and brave, confident, devoted to parents, respectful, diligent and thorough, honest and responsible, persistent, charitable, humble, simple, patient, forgiving, creative, hardworking, religious, and nationalist person. Then, the digital book H.B Jassin: Perawat Sastra Indonesia is used as a teaching material for Indonesian language learning at the high school level in grade $X$ at basic competencies 3.14 menilai hal yang dapat diteladani dari teks biografi.
\end{abstract}

Kata Kunci:

Keteladanan tokoh; Bahan ajar bahasa. Indonesia.

\section{Abstrak:}

Generasi muda mengalami permasalahan dalam mengenali tokoh-tokoh nasional yang sangat berjasa pada bangsa Indonesia. Melalui perpustakaan digital Kementerian Pendidikan dan Kebudayaan dengan situs budi.kemdikbud.go.id menyediakan buku-buku yang sangat bermanfaat bagi anak-anak dalam mengenali tokoh nasional Indonesia. Salah satu bukunya berjudul H.B Jassin: Perawat Sastra Indonesia yang berisi tentang seluk beluk tokoh H.B 
Jassin yang dapat diteladani. Keteladanan tersebut dapat dijadikan suri teladan bagi anak-anak dalam pengembangan karakter. Selain itu buku digital H.B Jassin: Perawat Sastra Indonesia dapat dimanfaatkan sebagai bahan ajar Bahasa Indonesia. Penelitian bertujuan mendeskripsikan sikap teladan tokoh H.B Jassin dan pemanfaatan buku digital H.B Jassin: Perawat Sastra Indonesia sebagai bahan ajar Bahasa Indonesia. Kualitatif deskriptif dipilih sebagai metode penelitian ini dan buku digital H.B Jassin: Perawat Sastra Indonesia sebagai sumber data. Dari hasil analisis ditemukan unsur keteladanan tokoh H.B. Jassin, yaitu gemar membaca, semangat dan pemberani, percaya diri,berbakti kepada orang tua, menghormati, tekun dan teliti, jujur dan bertanggung jawab, pantang menyerah, peduli sosial, rendah hati, sederhana, sabar, pemaaf, kreatif, pekerja keras, religius, dan cinta tanah air. Kemudian buku digital H.B Jassin: Perawat Sastra Indonesia dimanfaatkan untuk bahan ajar Bahasa Indonesia pada kelas X SMA pada KD 3.14 menilai hal yang dapat diteladani dari teks biografi.

\begin{tabular}{ccc}
\hline \hline Terkirim: 16-08-2021 & ; Revisi: 23-09-2021 & ; Diterima: 25-11-2021 \\
\hline \hline OGhâncaran: Jurnal Pendidikan Bahasa dan Sastra Indonesia \\
Tadris Bahasa Indonesia \\
Institut Agama Islam Negeri Madura, Indonesia
\end{tabular}

\section{PENDAHULUAN}

Seiring perkembangan zaman, generasi muda saat ini kesulitan dalam mengenali tokoh-tokoh yang berjasa pada kemajuan bangsa Indonesia. Generasi muda cenderung lebih mengenali publik figur yang sering muncul di media sosial atau media televisi. Padahal dari prestasi tokoh-tokoh bangsa, para generasi muda dapat belajar dan menjadikannya teladan. Para generasi muda dapat belajar dari pengalaman tokoh untuk memajukan negara serta bangsa. Senada dengan pendapat Sulistyo (2019) bahwa anak muda lebih menyukai dan membanggakan super hero dalam cerita fantasi dibandingkan tokoh-tokoh yang berpengaruh dalam kehidupan sesungguhnya.

Buku digital merupakan inovasi hasil teknologi dalam bidang pendidikan. Buku yang awalnya dapat diperoleh secara tercetak seiring perkembangan teknologi dapat diperoleh dalam format digital. Buku digital memiliki kelebihan-kelebihan dibandingkan buku tercetak. Buku digital cenderung mudah untuk diakses sewaktu-waktu tanpa harus berada di tempat tertentu. Buku digital dapat diakses melalui ponsel pintar, laptop, tab, dll. Salah satu laman yang menyediakan buku-buku digital adalah budi.kemdikbud.go.id. Laman tersebut menyajikan berbagai jenis buku bacaan, salah satunya buku digital tentang tokoh-tokoh nasional Indonesia yang dapat dijadikan bahan bacaan yang penuh inspirasi.

Salah satu tokoh Indonesia di bidang sastra adalah H.B. Jassin dan beliau orang yang memiliki rasa peduli yang tinggi terhadap karya sastra. Kiprah H.B. Jassin dalam 
dunia sastra Indonesia dapat diteladani oleh para siswa. Buku digital berjudul H.B. Jassin: Perawat Sastra Indonesia berisi riwayat singkat H.B. Jassin sebagai seorang kritikus sastra terkenal dan terbaik Indonesia. Melalui buku digital berjudul H.B. Jassin: Perawat Sastra Indonesia, siswa dapat belajar bahasa Indonesia pada materi teks biografi sekaligus menambah wawasan dari pengalaman H.B. Jassin sebagai tokoh sastra Indonesia. Siswa dapat meneladani kekonsistenan Jassin dalam merawat sastra Indonesia sehingga siswa dapat mencintai sastra Indonesia. Tafiyanti (2017:10) menjelaskan bahwa para tokoh yang biografinya ditulis adalah orang-orang yang memiliki perjalanan hidup yang mengesankan dan berkarakter dalam dirinya sehingga dapat dijadikan panutan.

Bahan ajar Bahasa Indonesia yang sering digunakan guru saat ini adalah buku paket Kurikulum 2013 saja. Hal itu menyebabkan guru sering terfokus pada sajian materi atau litiahn-latihan yang ada dalam buku teks,sehingga dibutuhkan alternatif bahan ajar untuk mendukung materi yang ada dalam buku paket Kurikulum 2013. Salah satu buku yang dapat dimanfaatkan untuk pembelajaran Bahasa Indonesia dalam teks biografi adalah buku digital H.B. Jassin: Perawat Sastra Indonesia. Menurut Astuti (2020:3) guru lebih sering menggunakan bahan pembelajaran berupa buku siswa dan lembar kerja siswa sehingga siswa memperoleh pengetahuan dan keterampilan yang terbatas. Hermawan dan Shandi (2019:11) menambahkan bahwa ketersediaan bahan ajar di sekolah cenderung kurang.

Penelitian mengenai unsur keteladanan tokoh pernah dilaksanakan oleh Rizki Sri Astuti (2020) berjudul Analisis Unsur Keteladanan Tokoh pada Biografi Sandiaga Uno sebagai Alternatif Bahan Ajar pada Peserta Didik Kelas X. Penelitian itu bertujuan menganalisis unsur keteladanan dalam biografi Sandiaga Uno dan kesesuaian unsur keteladanan Sandiaga sebagai alternatif bahan ajar kelas X. Persamaan penelitian yang sudah dilakukan tersebut dengan penelitian ini adalah menganalisis unsur keteladan tokoh Indonesia dan memanfaatkannya untuk bahan ajar. Perbedaannya adalah biografi tokoh yang dianalisis berbeda dan hal yang dikaji dalam penelitian ini dari buku digital laman budi.kemdikbud.go.id.

Berikutnya, penelitian Rendra Mahesa Putra (2020) berjudul Analisis Unsur Keteladanan pada Teks Biografi Abdurahman Wahid sebagai Alternatif Bahan Ajar Bahasa Indonesia Kelas $X$. Penelitian tersebut bertujuan untuk mengidentifikasi unsur keteladanan dalam teks biografi Abdurrahman Wahid dan memanfatkannya untuk bahan pembelajaran bahasa Indonesia. Persamaan penelitian itu dengan penelitian ini adalah menganalisis unsur keteladanan salah satu tokoh Indonesia dan memanfaatkan 
hasilnya untuk bahan ajar. Perbedaannya adalah biografi tokoh yang dianalisis berbeda dan sumber penelitian dalam penelitian ini adalah buku digital pada laman budi.kemdikbud.go.id. Berpijak pada pemaparan di atas, maka tujuan dari penulisan artikel ini adalah menganalisis unsur keteladanan tokoh pada buku digital H.B. Jassin: Perawat Sastra Indonesia dan mendeskripsikan pemanfaatan buku digital tersebut sebagai bahan ajar Bahasa Indonesia.

\section{METODE}

Untuk menjawab tujuan penelitian yang telah ditetapkan, penulis memilihi metode penelitian kualitatif deskriptif dengan alasan data yang dikumpulkan berupa narasi yang menunjukkan unsur keteladanan dari seorang tokoh H.B. Jassin. Buku digital yang diterbitkan oleh Kemendikbud dengan judul H.B.Jassin: Perawat Sastra Indonesia merupakan pemerolehan data. Kemudian data penelitian ini dapat berupa kata atau kalimat yang menunjukkan sikap teladan dari seorang H.B. Jassin. Dalam penyusunan artikel, penulis sebagai instrumen utama dalam mengumpulkan, mengidentfikasi, serta menyimpulkan dari analisis yang dilakukan.

Analisis isi merupakan cara yang diterapkan penulis dalam menganalisis data. Penulis dalam melaksanakan penelitian ini menerapkan prosedur penelitian yang meliputi: (1) membaca dengan cermat buku digital H.B. Jassin: Perawat Sastra Indonesia, (2) mengidentifikasi unsur keteladanan tokoh H.B Jassin dari buku digital H.B. Jassin: Perawat Sastra Indonesia, (3) menafsirkan unsur keteladanan tokoh tokoh H.B Jassin dari buku digital H.B. Jassin: Perawat Sastra Indonesia, dan (4) mengecek keabsahan data dengan teman sejawat yang dilaksanakan dengan penuh kehatianhatian dan ketekunan, dan (5) menarik simpulan.

\section{HASIL DAN PEMBAHASAN}

\section{Unsur Keteladanan Tokoh dalam Buku Digital H.B. Jassin: Perawat Sastra Indonesia}

Buku digital yang diterbitkan Kemendikbud menjelaskan kehidupan seorang sastrawan H.B Jassin yang memiliki nama lengkap, yaitu Hans Bague Jassin. Jassin nama panggilannya, lahir di Gorontalo pada 31 Juli 1917. Di tanah kelahirannya sebelum dibuka sekolah dasar, Jassin bersekolah kepada teman ayahnya, hingga di Gorontola didirikan sekolah untuk rakyat pribumi pada zaman Belanda yang dikenal dengan sekolah Holland Inlandsche School (HIS). Jassin anak yang cerdas, sehingga ketika masuk di sekolah tersebutJassin dimasukkan di kelas dua. 
Selesai sekolah dasar di Gorontalo, Jassin melanjutkan sekolah menengah pertama atau dikenal dengan sekolah Hogere Burger School (HBS) di Medan. Jassin berkawan dengan Chairil Anwar ketika berada di Medan. Perjumpaan mereka berawal dari acara kelompok pecinta baca dan olah raga. Dalam acara tersebut, Jassin juga berjumpa dengan Adinegoro yang merupakan wartawan tersohor pada masa itu. Jassin memiliki keinginan besar untuk berguru menulis berita kepada Adinegoro, sehingga memberanikan diri untuk berkunjung kekediaman Adinegoro dan menyampaikan tujuannya bahwa ingin belajar menulis berita.

Setelah lulus sekolah dari Medan, Jassin diminta untuk kembali ke Gorontalo oleh ayahnya. Dalam perjalanannya, Jassin berhenti di Jakarta dan berjumpa Sutan Takdir Alisyahbana. Dalam perjumpaanya tersebut Jassin dan Takdir berdiskusi banyak hal. Takdir merasa takjub dengan kepandaian Jassin dan merasa Jassin akan berguna jika bekerja di Balai Pustaka. Jassin yang menerima surat dari Takdir tentang lowongan pekerjaan di Balai Pustaka tidak dapat memenuhinya, karena Jassin harus pulang ke Gerontolo sesuai permintaan ayahnya.

Setahun berlalu, kemudian Jassin memutuskan untuk kembali ke Jakarta untuk bekerja di Balai Pustaka. Jassin menemui Takdir dan kemudian diterima bekerja di Balai Pustaka. Jassin bekerja dengan tekun dan seseorang yang gemar membaca dan teliti. Di tempat tersebut Jassin bekerja sampai pada tahun 1947 Jassin. Kemudian Jassin, pada tahun 1953 mengajar Fakultas Sastra, Universitas Indonesia karena dorongan teman-temannya serta sekaligus berkuliah di fakultas tersebut, sebab Jassin pada waktu itu belum sarjana.

Jassin terus berkecimpung dalam kesastraan Indonesia. Hal tersebut berawal ketika Jassin bekerja di Balai pustaka dan ditugaskan untuk mengulas buku. Dengan pengetahuan yang dimiliki Jassin tentang kaya sastra khususnya gaya menulis pengarang, Jassin berinisiatif untuk mengklasifikasikan pengarang-pengarang Indonesia berdasarkan tahun penulisan karya sastra. Untuk mendukung keinginan tersebut, Jassin menunjukkan hasil kerja kerasnya yang sudah dicetak dalam bentuk buku.

Jassin mendapatkan banyak julukan dan yang paling terkenal adalah "Paus Sastra" yang sebenarnya merupakan ejekan karena kesal kepada Jassin dianggap seperti paus pemimpin tertinggi umat Katolik Roma. Jassin juga dijuluki dokumentator sastra, pembela sastra Indonesia, perawat sastra Indonesia, kritikus sastra, juru bicara Angkatan 45, redaktur abadi, dan penerjemah, bahkan disebut juga sebagai pahlawan budaya. 
Pada tahun 1940 Jassin sudah berada di balai pustaka. Selama bekerja di sana, Jassin mengarsipkan tulisan-tulisan yang dimuat di majalah, karena Jassin berpikir suatu saat nanti majalah-majalah yang disimpan akan berguna. Selanjutnya yang disimpan Jassin tidak hanya berupa majalah, puisi, cerita atau ulasan, namun juga menyimpan berbagai hal yang berbau pengarang dan karya sastranya. Selain itu, juga berusaha mengalihbahasakan karya sastra berbahasa asing ke dalam bahasa Indonesia.

Pengharagaan-penghargaan yang diperoleh Jassin sangatlah banyak, karena kecintaannya terhadap karya sastra. Pada tahun 1969 Jassin memperoleh penghargaan dari pemerintah republik Indonesia, yaitu Satya Lencana Kebudayaan dari. Penampilan Jassin tidak pernah berubah meskipun mendapatkan banyak penghargaan, yaitu salah satunya dia pergi dan pulang dari kantor tetap dengan berjalan kaki. Jassin tutup usia pada tahun 2000. Orang-orang banyak berdatangan ke rumah duka untuk bertakziah dan mengirimkan doa untuk Jassin. Banyak orang yang merasa kehilangan atas kepergian Jassin karena bagi mereka sulit untuk menemukan orang-orang yang sangat mencintai karya sastra seperti H.B. Jassin.

Dari cerita singkat Jassin di atas banyak hal yang dapat diteladani dan dijadikan sebagai bahan pembelajaran di sekolah dalam mengembangkan pendidikan karakter peserta didik. Suriadi, dkk (2021) berpendapat bahwa pendidikan karakter merupakan suatu usaha untuk menanamkan sikap religius dan sosial pada diri generasi bangsa dalam mengembangkan pengetahuan dan keterampilan, sehingga terlahir para penerus bangsa yang sesuai dengan harapan dalam menghadapi perkembangan zaman.

Keteladanan dari seorang H.B. Jassin, yaitu gemar membaca. Menurut Sumiati, dkk (2021) gemar membaca adalah kedisiplinan seseorang dalam meluangkan waktu untuk menikmati bacaan-bacaan yang memberikan banyak manfaat untuk dirinya sendiri. Pernyataan tersebut sejalan dengan Jassin yang sejak kecil sudah senang membaca dengan selalu membacakan koran untuk ayahnya. Dari sikap gemar membaca, Jassin memperoleh banyak pengetahuan dan dia bisa menjadi seorang kritikus sastra yang handal. Dalam hal membaca, bacaan Jassin tidak terbatas pada buku saja berbagai jenis tulisan dibacanya. Sikap teladan Jassin tersebut, dapat dijadikan bahan dalam pengembangan pendidikan karakter karena dari delapan belas pendidikan karakter, gemar membaca adalah salah satu karakter yang harus diterapkan sejak dini pada diri anak-anak. Selain itu, dari kegemaran membaca Jassin 
guru dapat menanamkan pandangan kepada siswa bahwa dengan membaca seseorang menjadi berwawasan luas dan membawa kesuksesan.

Sikap semangat dan pemberani untuk belajar juga merupakan keteladanan yang dapat diteladani dari seorang Jassin. Makna semangat seringkali disamakan dengan motivasi. Motivasi adalah dorongan psikologis yang merupakan perubahan energi pada diri seseorang untuk tetap bersemangat dan bertahan melakukan sesuatu yang sesuai dengan arah dan tujuan yang ingin dicapainya secara sadar maupun tidak sadar (Badarudin, 2020). Kemudian yang dimaksudkan dalam analisis ini adalah motivasi atau semangat belajar dari seorang Jassin yang ingin belajar untuk menulis berita. Dalam hal ini semangat belajar yang dimaksudkan adalah dorongan energi seseorang untuk bertindak dalam mencapai harapan yang telah direncanakan agar dapat memperoleh pengalaman-pengalaman baru berupan pengetahuan, keterampilan, dan sikap. Semangat belajar diketahui dari Jassin yang ingin belajar menulis berita kepada seorang wartawan terkenal Adinegoro pada masa itu. Kemudian dengan rasa semangat belajar Jassin memiliki keberanian untuk bertamu ke rumah wartawan tersebut untuk menyampaikan keinginannya untuk belajar menulis berita. Pernyataan tesebut terdapat pada narasi "Tuan, saya ingin belajar menulis berita". Adinegoro memperhatikan Jassin.

Sikap percaya diri Jassin juga ditunjukkan ketika melakukan penolakan bersama para sastrawan yang tidak sependapat dengan PKI karena PKI melakukan segala cara termasuk dengan karya sastra untuk mewujudkan tujuan politik. Jassin bersama para sastrawan pendukungnya dengan percaya diri melakukan penolakan untuk membela yang benar dengan menyetujui surat pernyataan yang dikenal dengan Manifes Kebudayaan. Dari uraian tersebut menunjukkan bawa rasa percaya diri itu penting karena akan memunculkan keberanian dalam membela kebenaran. Maka dari itu rasa percaya diri harus dikembangkan sejak dini pada diri siswa. Syarif, dkk (2021) menjelaskan sikap dan karakter percaya diri sangat diharapkan tertanam dalam benak peserta didik karena dengan dorongan percaya diri, siswa lebih mampu untuk berani dalam melakukan tindakan dan mengemukaan gagasan dalam belajar, sehingga dalam hal ini, peran guru sangat diharapkan dalam menerapkan strategi pembelajaran yang dapat mengembangkan rasa percaya diri peserta didik dalam belajar. Salah satu strategi yang dalam mengembangkan rasa percaya diri dengan memberikan kisah-kisah para tokoh besar kepada siswa yang dapat dijadikan teladan, salah satunya, yaitu H.B. Jassin.

Unsur keteladanan dari seorang Jassin yang dapat diteladani adalah berbakti kepada orang tua. Hal tersebut diperlihatkan Jassin dengan menghormati keputusan 
ayahnya yang diwujudkan dengan mematuhi perintah ayahnya untuk kembali ke Gorontola setelah lulus sekolah di Medan, meskipun permintaan tersebut tidak sesuai dengan keinginan Jassin. Ichsanto dan Wahyuningsih (2021) menjelaskan menghormati kedua orang tua, yakni segala bentuk sikap baik yang dilaksanakan seorang anak untuk kedua orang tua, menjalankan semua perintah mereka, sebagai bentuk bakti kita terhadap mereka. Sikap berbakti kepada orang tua juga ditunjukkan Jassin dengan tidak menerima tawaran pekerjaan dari Sutan Takdir Alisyahbana untuk bekerja Jakarta, yaitu di Balai Pustaka dan tetap berkeja di Gorontalo sesuai dengan permintaan ayahnya.

Sikap menghormati Jassin tidak hanya ditunjukkan kepada ayahnya, namun juga kepada orang lain yang berada di sekitarnya. Sikap menghormati ditunjukkan Jassin ketika akan menemui Sutan Takdir Alisyahbana di Jakarta tepatnya di Balai Pustaka. Sebagai bentuk menghormati Takdir yang merupakan tokoh besar dan terkenal, Jassin tidak hanya menjaga sikapnya kepada Takdir, namun juga menjaga penampilan dengan berdandan rapi mengenakan jas dan dasi. Latuserimala dan Salong (2021) menguraikan bahwa seseorang yang selalu menghormati orang lain bermaksud untuk menjaga silaturahmi yang baik kepada orang-orang di sekitarnya agar terwujud kehidupan yang diharapkan.

Sikap tekun dan teliti juga melekat pada diri Jassin. Sikap tekun dan teliti tampak ketika Jassin di Balai Pustaka untuk bekerja. Di tempat tersebut dia selalu rajin dan selalu membaca dengan teliti buku-buku yang akan diulas. Afrianti dan Suyatno (2021) menjelaskan sikap rajin dapat dipahami dari sikap atau tindakan seseorang dalam menyelesaikan permasalahan yang dihadapi. Ketekukan dan ketelitian Jassin dilakukan dengan selalu mencatat kelebihanhan dan kekurangan buku yang dibaca. Tujuannya ketika Jassin atau orang lain membutuhkan ulasan buku tertentu dapat ditemukan dengan mudah karena sudah dicatat sebelumnya. Sebagai penggemar bacaan setiap selesai membaca buku, beliau memberikan tanda pada halaman terakhir yang dibaca dengan membubuhkan di tepi buku berupa tanggal dan paraf. Hal yang dilakukan oleh Jassin tersebut dapat dijadikan contoh oleh siswa dalam hal menandai bahan bacaan yang dijadikan sumber pengetahuan.

Jassin juga merupakan seseorang yang memiliki sikap tanggung jawab dan jujur. Kedua sikap tersebut muncul ketika Jassin membela karya sastra karangan Hamka dan Chairil Anwar yang dianggap menjiplak sastra asing. Jassin dengan jujur menjelaskan bahwa karya sastra yang dihasilkan memang benar-benar karya Hamka dan Chairil Anwar dengan mampu memberikan bukti-bukti yang dapat dipercaya. 
Kemudian Jassin, dengan bertanggung jawab memberikan bukti-bukti bahwa karya sastra yang dihasilkan oleh Hamka dan Chairil Anwar bukanlah hasil menjiplak, namun hanyalah pengaruh satu karya dengan karya yang lain. Abidin (2020) menjelaskan bahwa bertanggung jawab artinya seseorang yang memiliki sikap menerima segala sesuatu yang dibebankan kepada dirinya dan menyelesaikan apa yang diberikan dengan tepat waktu. Berdasarkan analisis penulis, sikap bertanggung jawab Jassin ditunjukkkan dengan beliau berani mempertanggungjawabkan atas bukti-bukti yang ditunjukkan. Kejujuran dan bertanggung jawab juga merupakan karakter yang penting untuk dikembangkan karena berperan penting dalam tingkah laku pada diri anak dalam menghadapai perkembangan zaman. Maka dari itu, orang tua dan guru sangat diharapkan perannya dalam pengembangan sikap jujur dan bertanggung jawab dalam diri anak. Selanjutnya sikap tanggung jawab Jassin juga ditunjukkan ketika Jassin mampu menyelesaikan sekolah di Medan sesuai dengan ketentuan. Hal itu ditunjukkan pada narasi "Jassin menyelesaikan sekolah di Medan tepat waktu".

Sikap pantang menyerah juga merupakan sikap teladan dari seorang Jassin yang dapat kita teladani. Ketika itu Jassin diejek dan dianggap tidak menguasai bahasa Arab dan bukan ahli agama Islam untuk dapat menerjemahkan Al-Qur'an. Ejekanejekan yang diarahkan kepada Jassin, tidak membuat Jassin pantang menyerah dalam menerjemahkan Al-Qur'an. Jassin dengan tekun terus-menerus mencoba menerjemahkan bahasa Arab pada Al-Qur'an ke dalam Bahasa Indonesia. Sikap tidak putus asa Jassin dalam mencapai tujuannya ditunjukkan pada narasi "Jassin tidak berputus asa dalam menerjemahkan Al-Qur'an".

Sikap pantang menyerah juga ditunjukkan oleh Jassin ketika membela rekanrekannya yang dituduh menjiplak karya orang lain. Nurjannah, dkk. (2021) menjelaskan bahwa pantang menyerah adalah tindakan seseorang untuk terus-menerus berusaha dalam semua kondisi untuk mencapai tujuan yang diinginkan demi kebaikan hidupnya. Sikap gigih Jassin tersebut mendapatkan gelar sebagai seorang pembela sastra. Dari narasi yang disajikan tampak keteguhan hati seorang Jassin tidak berputus asa untuk menyakini bahwa karya sastra yang dihasilkan oleh Hamka dan Chairil Anwar bukan merupakan hasil menjiplak. Novel karangan Hamka dengan judul Kapal van der Wick dituduh meniru karya sastra yang ditulis oleh orang Arab, sedangan puisi karangan Cahiril Anwar Krawang Bekasi dituduh menjiplak puisi seorang penyair Amerika. Jassin bersikap gigih atau pantang menyerah menolak atas tuduhan-tuduhan tersebut karena Jassin dapat membuktikan bahwa Hamka dan Chairil Anwar tidak menjiplak karya sastra asing. Kemudian dari kutipan-kutipan yang disajikan tersebut juga menunjukkkan 
sikap peduli sosial Jassin, terhadap rekan-rekannya yang dituduh melakukan sesuatu hal yang tidak pernah dilakukan. Sikap peduli sosial Jassin ditunjukkan dengan membela rekan-rekannya bahwa tuduhan yang diberikan tidak tepat dan Jassin membuktikan bahwa karya yang dihasilakn rekan-rekannya bukanlah dari menjiplak. Kepedulian yang ditunjukkan Jassin merupakan peduli sosial, yang artinya kondisi perasaan atau perbuatan seseorang turut serta merasakan kesenangan atau kesedihan orang lain. Senada dengan pendapat Nugroho (2021) bahwa peduli sosial adalah perasaan yang muncul dengan penuh kesadaran pada diri seseorang dengan menumbuhkan rasa saling mengasihani dan peduli terhadap kehidupan orang lain.

Banyak julukan yang diterima oleh Jassin, namun hal tersebut tidak membuatnya sombong atau berbangga hati. Beliau tetap dengan kerendahan hati atas prestasiprestasi yang diperoleh. Basiroh (2017) menjelaskan bahwa rendah hati adalah sikap seseorang yang selalu ditunjukkan dengan cara sopan dan santun baik dalam perbuatan maupun perkataan. Hal tersebut sejalan dengan sikap Jassin yang tidak sombong dan bersikap biasa saja atas prestasi-prestasi yang diperoleh. Kemudian tidak hanya sikap rendah hati yang dapat diteledani dari seorang Jassin, sikap sederhana juga sangat menonjol pada diri seorang Jassin. Jassin yang mendapat banyak penghargaan dan julukan-julukan karena kecintaannya kepada karya sastra tidak membuat sikap Jassin menjadi berlebihan, namun Jassin selalu bersikap sederhana. Selain itu juga kesederhaan Jassin juga dibuktikan pada keseharian Jassin, yaitu dengan berangkat dan pulang bekerja dengan berjalan kaki, meskipun Jassin sudah menjadi tokoh besar.

Selain unsur-unsur keteladanan yang telah dijelaskan di atas, dari analisis yang dilakukan penulis pada buku digital H. B. Jassin: Perawat Sastra Indonesia ditemukan kembali hal yang dapat diteladani dari seorang H.B. Jassin, yaitu kesabaran. Pada biografi ini diceritakan secara jelas Jassin bersikap sabar terhadap Armijn Panen yang telah menolak puisi Chairil Anwar yang tidak cocok dengan semangat kebangsaan. Jassin dengan sabar menerima penolakan yang dilakukan oleh Armijn Pane dan mengikuti keinginan Armijn Pane untuk tidak menerbitkan pusi Chairil Anwar, meskipun Jassin sebenarnya menyukai puisi karangan Chairil Anwar. Sabar adalah sikap seseorang yang mampu mencegah kemarahan dan dapat mengendalikan dirinya untuk melakukan tindakan-tindakan yang melanggar aturan (Rahmah, dkk., 2021). Kesabaran Jassin juga ditunjukkan dengan ketika Jassin menghadapi sikap Chairil Anwar yang suka semaunya sendiri dan membuat kesal orang lain. Contohnya, Chairil datang ke rumah Jassin tanpa memperhatikan waktu, datang ke rumah Jassin hanya 
untuk menumpang makan, dan datang ke rumah Jassin dengan naik becak tetapi meminta Jassin untuk membayarinya, namun hal tersebut diterima dengan sabar oleh Jassin.

Jassin juga seseorang yang mudah memaafkan. Sikap memaafkan tersebut tampak pada narasi ketika Jassin dibuat kesal dengan sikap Chairil, sehingga terjadi keributan di antara keduanya karena Chairil mengejek Jassin, padahal saat itu Jassin akan segera tampil untuk bermain sandiwara. Namun Jassin tidak berlarut-larut pada kemarahan karena sikap Chairil yang menjengkelkan, karena kelembutan hati yang dimiliki Jassin, dia menyadari sifat dari Chairil dan memaafkan perbuatannya.

Kreatif merupakan sikap teladan yang melekat pada diri Jassin. Kreatif diartikan sebagai inisiatif yang muncul dari diri seseorang untuk menciptakn hal-hal yang menarik dari hal-hal yang sebelumnya sudha ada atau belum ada (Pradana, 2021). Jassin yang merupakan penggemar bacaan merasa tidak cukup jika hanya mengandalkan bacaan dari perpustakaan. Maka dari itu Jassin menciptakan sesuatu yang baru dengan mengarsipkan buku-buku khusunya buku kesastraan. Kemudian memfortofoliokan guntingan koran serta majalah yang dilakukan selama bertahun-tahun. Kebiasaan Jassin tersebut direspon oleh Ali Sadikin Gubenur Jakarta saat itu, dengan memberikan solusi kepada Jassin atas kebiasaannya tersebut dengan berupaya memberikan sarana untuk menyimpan koleksi buku-buku sastra dan kliping Jassin di gedung kompleks Taman Ismail Marzuki, Jakarta.

Sikap bekerja keras juga melekat pada diri Jassin. Iskandar dan Suyatno (2021) menjelaskan bahwa kerja keras adalah sikap atau perbuatan seseorang yang selalu terus-menerus berusaha untuk mendapatkan tujuan yang diinginkan. Tujuan Jassin adalah agar masyrakat dapat dengan mudah membaca karya sastra. Hal itu ditunjukkan Jassin dengan mengumpulkan buku-buku sastra serta potongan majalah dan koran. Bertahun-bertahun Jassin melakukan hal tersebut tanpa lelah hingga buku dan klipping yang disimpan di dalam map bertumpuk menjadi banyak. Selain orang yang cinta kepada sastra, Jassin juga merupakan orang yang berkarakter religius. Kereligiusan Jassin ditunjukkan ketika menghilangkan rasa kesedihan ditinggal istrinya meninggal dengan selalu mendokan istrinya kepada Allah Swt. dan terus-menerus membaca Al-Qu'an. Kemudian sikap religius Jassin juga ditunjukkan dengan Jassin menghapal Al-Qur'an ketika berangkat ke kantor dengan jalan kaki. Nugroho (2021) menjelaskan karakter religius adalah perbuatan seseorang berdasarkan atas kepercayaan yang dianut dengan menjalankan sesuatu sesuai dengan ajarannya. 
Seseorang yang memperlihatkan jiwa peduli dan berkorban untuk negara dan bangsanya demi kemajuan bangsanya merupakan sikap cinta tanah air. Kemendikbud (2011) menjelaskan cinta tanah air adalah cara berpikir,bersikap dan berbuat yang menunjukkan kesetiaan, kepedulian dan penghargaan yang tinggi terhadap bahasa, lingkungan fisik, sosial, budaya, ekonomi dan politik bangsanya. Hal tersebut ditunjukkan oleh Jassin dengan sikap peduli dan menghargai karya sastra sebagai khazanah bangsa Indonesia. Jassin mencintai karya sastra dengan mengumpulkan berbagai hal yang berkaitan dengan kesastraan. Kemudian Jassin mendapatkan berbagai julukan karena cintanya kepada sastra, salah satunya adalah "dokumentator sastra". Dari julukan yang diberikan kepada Jassin menunjukkan bahawa Jassin adalah orang yang cinta tanah air dengan menunjukkan rasa peduli terhadap karya sastra dengan mengumpulkan berbagai hal yang berkaitan dengan karya sastra. Selanjutnya rasa cinta tanah air Jassin yang dibuktikan dengan kecintaannya kepada sastra ditunjukkan dengan dengan mendokumentasikan segal hal yang berkaitan dengan karya sastra baik puisi, cerita, dan ulasan dari koran. Hal tersebut menunjukkan Jassin orang yang memiliki rasa peduli dan cinta kepada karya sastra, sehingga Jassin dengan senang dan sukarela mengumpulkan berbagai hal yang berkiatan dengan kesastraan agar tetap dapat dinkmati oleh para pembaca.

\section{Pemanfaatan Buku Digital H.B. Jassin: Perawat Sastra Indonesia Sebagai Bahan} Ajar Bahasa Indonesia

Buku digital merupakan bukti nyata perkembangan teknologi yang dapat dijadikan alternatif dalam pelaksanaan pembelajaran. Apalagi saat Covid-19 yang menuntut pembelajaran jarak jauh, penggunaan buku digital dapat menjadi hal penting dalam sebuah pembelajaran. Buku digital dapat dimanfaatkan sebagai bahan ajar dalam pembelajaran jarak jauh maupun tatap muka di kelas. Hal ini bergantung pada materi ajar serta alat untuk menampilkan buku digital. Senada dengan pendapat Astawa dan Nengah bahwa buku digital dapat digunakan dalam pembelajaran sinkron maupun asinkron (2020:143).

Dalam penggunaan buku digital, tidak memerlukan kemampuan khusus dari guru. Jadi, buku digital dapat dimanfaatkan dengan mudah. Apalagi saat ini Kemendikbud dan beberapa laman lain peduli pendidikan sudah menyediakan bukubuku digital yang dapat diakses secara gratis dengan genre bermacam-macam. Hal ini membuat buku digital dapat dengan mudah diperoleh dan dijadikan bahan ajar. Sebagai bahan ajar, buku digital dapat menjadi pendukung target pembelajaran agar 
maksimal. Menurut Yaqin dan Rochmawati (2017:1) bahan ajar merupakan salah satu komponen penunjang untuk mencapai target pembelajaran. Bahan ajar yang efektif dan bervariasi dapat meningkatkan keaktifan dan motivasi siswa dalam belajar.

Pemanfaatan buku digital H.B. Jassin: Perawat Sastra Indonesia sebagai bahan ajar Bahasa Indonesia dapat ditinjau dari tiga hal yaitu perencanaan, pelaksanaan, hingga evaluasi pembelajaran. Perencanaan pembelajaran mengacu pada persiapan dari penggunaan bahan ajar. Tahap perencanaan, guru dapat mengidentifikasi unsurunsur keteladanan yang terdapat pada buku digital H.B. Jassin: Perawat Sastra Indonesia. Lalu, menyusun rencana pelaksanaan pembelajaran dengan menggunakan buku digital tersebut. Perencanaan pembelajaran ini dapat disusun berdasarkan Kompetensi Dasar (KD) 3.14 menilai hal yang dapat diteladani dari teks biografi. Kompetensi dasar ini diajarkan pada jenjang SMA pada kelas X. Berikut ini disajikan tabel 1 mengenai tujuan pembelajaran dari KD 3.14.

\begin{tabular}{lllll}
\hline \multicolumn{3}{c}{ Kompetensi Dasar } & \multicolumn{4}{c}{ Tujuan Pembelajaran } \\
\hline 3.14 & $\begin{array}{c}\text { Menilai hal yang dapat } \\
\text { diteladani dari teks biografi }\end{array}$ & 1. Siswa mampu menjelaskan isi teks biografi tokoh. \\
\cline { 3 - 5 } & & 2. Siswa mampu menilai hal-hal yang dapat \\
& & diteladani dari teks biografi tokoh.
\end{tabular}

Tabel 1: Tujuan Pembelajaran KD 3.14

Pembelajaran yang dilaksanakan dengan memanfaatkan buku digital H.B. Jassin: Perawat Sastra Indonesia sebagai bahan ajar Bahasa Indonesia terdapat tiga kegiatan pokok yaitu kegiatan pendahuluan, kegiatan inti, dan kegiatan akhir. Kegiatan awal merupakan bagian awal yang dilaksanakan oleh guru dan siswa dalam memulai pembelajaran. Kegiatan inti terdiri dari aktivitas siswa dan guru dalam pembelajaran menggunakan bahan ajar berupa buku digital H.B. Jassin: Perawat Sastra Indonesia. Kemudian, kegiatan penutup merupakan kegiatan akhir dari pembelajaran yang berisi simpulan terkait pembelajaran yang telah dilaksanakan.

Kegiatan pendahuluan terdiri dari aktivitas awal untuk memulai pembelajaran. Berikut ini rincian kegiatan pendahuluan dalam pembelajaran kompetensi 3.14 menggunakan bahan ajar buku digital H.B. Jassin: Perawat Sastra Indonesia. (1) Pendidik dan peserta didik berbalas salam dan berdoa berdasarkan kepecayaan masing-masing; (2) pendidik memeriksa kehadiran siswa; (3) apersepsi dengan tanyajawab tentang tokoh-tokoh nasional Indonesia; (4) siswa melihat tayangan video mengenai tokoh-tokoh nasional Indonesia; (5) guru menginformasikan tujuan pembelajaran berdasarkan KD akan dipelajari; (6) siswa membentuk kelompok yang beranggotakan 4 orang. 
Kegiatan berikutnya kegiatan inti. Dalam pelaksanaan kegiatan tersebut berdasarkan Kurikulum 2013 diterapkan pendekatan saintifik. Kegiatan ini berisi aktivitas utama dalam pembelajaran menilai teks biografi menggunakan buku digital H.B. Jassin: Perawat Sastra Indonesia. Terdapat lima aktivitas dalam kegiatan inti sesuai pendekatan saintifik Kurikulum 2013. Hal ini senada dengan pendapat Kurniasari (2017:10) bahwa pendekatan saintifik meliputi lima kegiatan yaitu mengamati, menanya, mengeksplorasi/mengumpulkan informasi, mengasosiasi/menalar, dan mengomunikasikan.

\section{Mengamati}

Kegiatan mengamati merupakan kegiatan pertama dalam pendekatan saintifik. Kegiatan ini bertujuan agar siswa dapat mengidentifikasi atau menemukan masalah terkait pembelajaran. Guru dapat mengarahkan siswa untuk membaca, melihat, atau menyimak tentang teks biografi. Guru menyajikan buku digital H.B. Jassin: Perawat Sastra Indonesia untuk dibaca dan dipahami isinya. Penyajian buku digital apabila pembelajaran jarak jauh dapat dikirim ke gawai masing-masing siswa. Jadi, siswa dapat melihat dan membaca pada gawai masing-masing. Apabila pembelajaran tatap muka di ruang kelas, maka guru dapat menyajikannya dengan bantuan LCD. Dengan kegiatan ini siswa diharapkan memiliki pengalaman langsung dalam memperoleh fakta tentang teks biografi yang akan dipelajarinya.

\section{Menanya}

Tahap kedua adalah kegiatan menanya. Kegiatan ini bertujuan agar siswa dapat memperoleh informasi tambahan terkait hal yang sudah dibaca, dilihat, atau disimaknya. Pada aktivitas ini, guru dapat membuka peluang kepada siswa untuk bertanya tentang isi teks biografi yang sudah dibaca. Kemampuan yang dikembangkan dalam pengalaman langsung untuk bertanya adalah berpikir kritis, rasa ingin tahu, dan merumuskan pertanyaan yang sesuai dengan konteks. Hal ini senada dengan gagasan Kurniasari (2017:13) bahwa kompetensi yang dibangun dari pengalaman langsung 'menanya' yaitu menumbuhkan rasa ingin tahu, kreativitas, dapat menyusun pertanyaan, dan berpikir kritis.

\section{Mengeksplorasi/Mengumpulkan Informasi}

Tahap selanjutnya adalah mengeksplorasi atau mengumpulkan informasi. Tahap ini adalah tindak lanjut dari 'menanya'. Kegiatan tersebut dilaksanakan dengan menemukan berbagai infomasi dari berbagai sumber. Oleh karena itu, siswa dapat melakukannya dengan membaca buku lain yang relevan, mengamati fenomena atau objek tertentu dengan lebih teliti, dan melaksanakan percobaan. Pada tahap ini, siswa 
bersama kelompok dapat mendiskusikan isi teks biografi yang dibaca. Kemudian, siswa secara berkelompok dapat menjelaskan isi teks biografi dalam buku digital H.B. Jassin: Perawat Sastra Indonesia. Selanjutnya, siswa bisa meneliti lebih lanjut isi dari teks biografi untuk mengumpulkan informasi seakurat mungkin. Selain itu, siswa mencari berbagai referensi untuk mendukung hasil diskusinya.

\section{Mengasosiasi/Menalar}

Selanjutnya adalah tahap mengasosiasi atau menalar. Siswa pada tahap ini secara berkelompok menilai hal yang dapat dijadikan teladan dari teks biografi H.B. Jassin yang telah dibaca. Siswa mengolah informasi yang ada. Lalu, siswa secara berkelompok membandingkan hasil pekerjaannya dengan kelompok lain. Apabila terdapat koreksi dari kelompok lain, maka siswa mengecek ulang pekerjaannya dan memperbaikinya. Menurut Kurniasari (2017:13) 'mengasosiasi' mengarah pada mengklasifikasi berbagai inisiatif dan membadingkan fenomena-fenomena selanjutnya menginterprestasikan dalam pikiran.

\section{Mengomunikasikan}

Guru memberikan kesempatan bagi para siswa secara individu maupun secara berkelompok untuk mengomunikasikan hal yang sudah dipelajari. Siswa dapat mempresentasikan hasil pekerjaanya. Siswa lain dapat memberikan umpan balik berupa komentar atau pendapat terkait hasil pekerjaan temannya. Lalu, guru memberikan respon dari hasil presentasi siswa dan pendapat dari siswa lain. Hal ini agar para siswa mengetahui hal yang dikerjakannya sudah benar atau masih perlu diperbaiki. Menurut Kurniasari (2017:14) kegiatan mengomunikasikan bertujuan untuk memberikan pengalaman belajar bagi siswa dalam mengomunikasikan gagasannya, menyampaikan hasil pengamatannya, menyimpulkan hal-hal yang telah dipelajarinya secara lisan maupun tertulis dll.

Kegiatan akhir adalah kegiatan penutup. Kegiatan ini merupakan kegiatan akhir pembelajaran. Guru dan siswa saling merespon tentang hal-hal yang telah dipelajari, menyimpulkan hal yang sudah dipelajari, dan kesulitan maupun kendala yang dialami siswa saat pembelajaran berlangsung. Selain itu, guru dapat memberikan evaluasi terhadap kegiatan pembelajaran maupun hasil belajar siswa. Guru dapat memberikan tambahan pengetahuan bagi siswa yang sudah mampu mengikuti pembelajaran dengan baik. Di samping itu, guru dapat merencanakan remedial bagi siswa yang belum mampu mendapat nilai sesuai KKM. Selanjutnya pembelajaran diakhiri dengan doa dan salam dari siswa dan guru. 
Kegiatan evaluasi dilaksanakan menggunakan instrumen autentik. Faizah menjelaskan bahwa penilaian autentik mampu mendeskripsikan sikap, pengetahuan, keterampilan yang sudah diperoleh siswa Berdasarkan hal tersebut, guru dapat menentukan materi layak dilanjutkan atau tidak (2015:32). Guru dapat menggunakan rubrik penilaian sesuai indikator untuk menilai pengetahuan siswa pada pembelajaran teks biografi ini. Berikut ini merupakan instrumen untuk menilai keberhasilan siswa dalam pembelajaran teks biografi untuk menentukan sikap teladan dari buku biografi dengan memanfaatkan buku digital H.B. Jassin: Perawat Sastra Indonesia.

\begin{tabular}{|c|c|c|c|}
\hline Aspek & Deskriptor & $\begin{array}{c}\text { Skor } \\
\text { Kriteria }\end{array}$ & $\begin{array}{l}\text { Skor yang } \\
\text { Diperoleh } \\
\text { Siswa }\end{array}$ \\
\hline \multirow[t]{3}{*}{$\begin{array}{l}\text { 1. Menjelaskan isi teks biografi } \\
\text { tokoh }\end{array}$} & $\begin{array}{l}\text { Siswa mampu menjelaskan } \\
\text { keseluruhan isi teks biografi } \\
\text { tokoh }(5 \mathrm{~W}+1 \mathrm{H})\end{array}$ & 40 & \multirow[t]{3}{*}{$\ldots$} \\
\hline & $\begin{array}{l}\text { Siswa mampu menjelaskan } \\
\text { sebagian isi teks biografi tokoh } \\
(3 \mathrm{~W}+1 \mathrm{H})\end{array}$ & 30 & \\
\hline & $\begin{array}{ll}\text { Siswa kurang } & \text { mampu } \\
\text { menjelaskan isi } & \text { teks } \\
\text { tokoh }(1 \mathrm{~W}+1 \mathrm{H}) & \end{array}$ & 20 & \\
\hline \multirow[t]{4}{*}{$\begin{array}{l}\text { 2. Menilai hal yang dapat } \\
\text { diteladani dari teks biografi }\end{array}$} & $\begin{array}{l}\text { Siswa mampu menilai } 20 \text { hal } \\
\text { yang dapat diteladani dari buku } \\
\text { biografi }\end{array}$ & 60 & \multirow[t]{3}{*}{$\cdots$} \\
\hline & $\begin{array}{l}\text { Siswa mampu menilai } 15 \text { hal } \\
\text { yang dapat diteladani dari buku } \\
\text { biografi }\end{array}$ & 50 & \\
\hline & $\begin{array}{l}\text { Siswa mampu menilai } 10 \text { hal } \\
\text { yang dapat diteladani dari buku } \\
\text { biografi }\end{array}$ & 40 & \\
\hline & Jumlah & & \\
\hline
\end{tabular}

Tabel 2 Rubrik Penilaian Kompetensi Dasar 3.14

\section{SIMPULAN}

Dari hasil analisis yang dilakukan oleh penulis, ditemukan unsur keteladanan tokoh H.B. Jassin dalam buku digital yang berjudul H.B. Jassin: Perawat Sastra Indonesia yang meliputi gemar membaca, semangat dan pemberani, percaya diri,berbakti kepada orang tua, menghormati, tekun dan teliti, jujur dan bertanggung jawab, pantang menyerah, peduli sosial, rendah hati, sederhana, sabar, pemaaf, kreatif, pekerja keras, religius, dan cinta tanah air. Kemudian pemanfaatan buku digital dengan judul $H . B$ Jassin: Perawat Sastra Indonesia dapat dimanfaatkan sebagai altenatif bahan ajar Bahasa Indonesia pada jenjang SMA kelas X pada Kompetensi Dasar (KD) 3.14 menilai hal yang dapat diteladani dari teks biografi. 


\section{DAFTAR RUJUKAN}

Abidin, N.Z. (2020), Literasi Membaca sebagai Upaya Pembentuk Karakter Peserta Didik (Jujur dan Bertanggungjawab). Prosiding Seminar Nasional Pascasarjana UNNES.

Afrianti, Z.R. dan Suyatno. (2021). Nilai Pendidikan Karakter dalam Novel Si Anak Pinta Karya Tere Liye (Perspektif Nilai Karakter John Garmo). BAPALA, 8(03), 59-70, diakses pada 7 Agustus 2021, dari https://ejournal.unesa.ac.id/index.php/bapala/article/view/39936.

Astawa, N. L.P. N. S. P. dan Nengah Widya Utami. (2020). Pelatihan Pembuatan Buku Cerita Digital Sederhana sebagai Bahan Ajar dalam Kondisi New Normal. Jurnal Karya Abadi, 4(1): 143-147, diakses pada 3 Agustus 2021, dari https://onlinejournal.unja.ac.id/JKAM/article/view/9832/5693

Astuti, R. S. (2020). Analisis Unsur Keteladanan Tokoh pada Biografi Sandiaga Uno sebagai Alternatif Bahan Ajar pada Peserta Didik Kelas X. Skripsi tidak diterbitkan. Bandung: Universitas Pasundan Bandung.

Badarudin, Achmad. (2015). Peningkatan Motivasi Belajar Siswa Melalui Konseling Klasikal. Jakarta: Abe Kreatifindo.

Basiroh, Umi. (2017). Peningkatan Hasil Belajar dan Imtak pada Materi Rendah Hati, Hemat, dan Sederhana Melalui 3 Steps of Role Playing Based on Daily Short Story Kelas VII. Jurnal Profesi Keguruan, 3(1): 80-91, diakses pada 7 Agustus 2021, dari https://journal.unnes.ac.id/nju/index.php/jpk/article/view/10485/7030.

Ichsanto, W. dan Wahyuningsih, R. (2021). Kemampuan Membaca Al-Qur'an dan Menghormati Orang Tua dengan Prestasi Belajar PAI Siswa SMP Surakarta. Cendekia: Journal of Education and Teaching, 15(1): 78-88, diakses pada 7 Agustus 2021, dari https://cendekia.soloclcs.org/index.php/cendekia/article/view/662.

Iskandar, N.P. dan Suyatno. (2021). Moral dan Karakter dalam Dongeng Putri Dewi Sekararum dan Raja Jin Pohon Delima Karya Nurul Ihsan (Kajian Sastra Anak). Bapala, 8(3):170-178, diakses pada 7 Agustus 2021, dari https://ejournal.unesa.ac.id/index.php/bapala/article/view/40217.

Faizah, Umi. (2015). Penerapan Pendekatan Saintifik melalui Model Project Based Learning untuk Meningkatkan Keterampilan Proses dan Hasil Belajar Siswa Kelas IV SD Negeri Seworan, Wonosegoro. Scholaria: Jurnal Pendidikan dan Kebudayaan, 5(1): 24-38, diakses pada 4 Agustus 2021, dari https://ejournal.uksw.edu/scholaria/article/view/4/492.

Hermawan, D. dan Shandi. (2019). Pemanfaatan Hasil Analisis Novel Seruni Karya Almas Suffeya sebagai Bahan Ajar Sastra di SMA. Metamorfosis: Jurnal Bahasa, Sastra Indonesia dan Pengajarannya, 12(1): 11-20, diakses pada 1 Agustus 2021, dari http://unibba.ac.id/ejournal/index.php/metamorfosis/article/view/125/127.

Kemendikbud. (2011). Pedoman Pelaksanaan Pendidikan Karakter. Jakarta: Kementrian Pendidikan Nasional Badan Penelitian dan Pengembangan Pusat Kurikulum dan Perbukuan.

Kurniasari, Fitri. (2017). Implementasi Pendekatan Saintifik pada Penugasan Aktivitas di Buku Teks Bahasa Indonesia Kelas VII SMP Berdasarkan Kurikulum 2013. Jurnal Pendidikan Edutama, 4(1): 9-26, diakses pada 4 Agustus 2021, dari https://www.ejurnal.ikippgribojonegoro.ac.id/index.php/JPE/article/view/44/41.

Latuserimala, P. dan Salong, F.A. (2021). Analisis Sikap Sosial Mahasiswa Melalui Mata Kuliah Studi Masyarakat Indonesia pada Program Studi Pendidikan Ekonomi FKIP UNPATI Ambon Tahun Akademik 2018/2019. JURNAL ILMU PENDIDIKAN EKONOMI (JPE), 1(1): 1-10, diakses pada 7 Agustus 2021, dari https://ojs3.unpatti.ac.id/index.php/jpe/article/view/3502/2755. 
Nugroho, A.F. (2021). Pembentukan Karakter Religius dan Sikap Peduli Sosial Peserta Didik Sekolah Menengah Kejuruan Negeri Jawa Tengah di Purbalingga. Tesi tidak diterbitkan. Purwokerto: IAIN Purwokerto.

Nurjannah, Radhiah, dan Trisfayani. (2021). Analisis Nilai Patriotisme Novel 693 KM Jejaj Gerilya Sudirman Karya Ayi Jufridar. Jurnal Metamorfosa, 9(2): 188-206, $\begin{array}{lllll}\text { diakses } & \text { pada } & 7 & \text { Agustus } & \\ \end{array}$ https://ejournal.bbg.ac.id/metamorfosa/article/view/1428.

Pradana, H.E.K. (2021). Nilai-Nilai Karakter dalam Film Animasi Up dan Relevansinya dengan Pendidikan Karakter Kerja Keras, Kreatif, dan Peduli Sosial Bagi Siswa SD/MI. Skripsi tidak diterbitkan. Ponorogo: Institut Agama Islam Negeri Ponorogo.

Putra, R. M. (2020). Analisis Unsur Keteladanan pada Teks Biografi Abdurahman Wahid sebagai Alternatif Bahan Ajar Bahasa Indonesia Kelas X. Skripsi tidak diterbitkan. Bandung: Universitas Pasundan Bandung.

Rahmah,N., Priyadi, A.T., Dan Syam, C. (2021). Analisis Karakter Tokoh dalam Novel Cinta 3 Benua Karya Faris $\mathrm{BQ}$ dan Astrid Tito. Jurnal Pendidikan dan Pembelajaran Khatulistiwa, 10(6):1-12, diakses pada 7 Agustus 2021, dari https://jurnal.untan.ac.id/index.php/jpdpb/article/view/47422/75676589642.

Sulistyo, E. (2019). Pahlawan di Era Milenial. Berita Satu. Diakses 1 Agustus 2021 dari https://www.beritasatu.com/opini/6421/pahlawan-di-era-milenial.

Sumiati, Sulistyarini, dan Hartoyo, Agung. (2021). Analisi Pendidikan Karakter Gemar Membaca dalam Kultur Sekolah Dasar Negeri 46 Kota Singkawang. Jurnal Pendidikan dan Pembelajaran Khatulistiwa, 10(6): 1-10, diakses pada 7 Agustus 2021, dari https://jurnal.untan.ac.id/index.php/jpdpb/article/view/47700/75676589777.

Suriadi, H.J., Firman, dan Ahmad, R. (2021). Analisis Problema Pembelajaran Daring Terhadap Pendidikan Karakter Peserta Didik. Edukatif: Jurnal IImu Pendidikan, 3(1):165-173, diakses pada 7 Agustus 2021, dari https://www.edukatif.org/index.php/edukatif/article/view/251/pdf.

Syarif, I., Elihami, dan Buhari, G. (2021). Mengembangkan Rasa Percaya Diri Melalui Strategi Peer Tutoring di Sekolah Dasar. EduPsyCouns Journal: Jurnal of Education, Psychology, and Counseling, 3(1): 69-77, diakses pada 7 Agustus 2021, dari https://ummaspul.e-journal.id/Edupsycouns/article/view/1262.

Tafiyanti, R. (2017). Pengembangan Bahan Ajar Menulis Teks Biografi melalui Media Animasi Berbasis Pendidikan Karakter. Tesis tidak diterbitkan. Bandung: Universitas Pendidikan Indonesia.

Yaqin, Y. dan Rochmawati. (2017). Pengembangan Buku Saku Digital Berbasis Android sebagai Pendukung Bahan Ajar pada Materi PPh Pasal 21. Jurnal Pendidikan Akuntansi. 5(1): 1-5, diakses 3 Agustus 2021, dari https://ejournal.unesa.ac.id/index.php/jpak/article/view/17965/16333. 